\title{
Molecular Characterization of Staphylococcus aureus of Camel (Camelus dromedarius) Skin Origin
}

\author{
Chandra Pratap Singh ${ }^{1}$, Manisha Mathur ${ }^{1}$, Hemant Dadhich $^{1}$ and Subha Ganguly ${ }^{2}$
}

${ }^{1}$ Department of Veterinary Pathology, College of Veterinary and Animal Science (Rajasthan University of Veterinary and Animal Sciences), Bikaner - 334001, Rajasthan, India ${ }^{2}$ Department of Veterinary Microbiology, Arawali Veterinary College (Affiliated to Rajasthan University of Veterinary and Animal Sciences, Bikaner), N.H. - 52 Jaipur Road, V.P.O. Bajor, Sikar-332001, Rajasthan, India

*Corresponding author

\section{A B S T R A C T}

\section{Keywords}

Camel skin, Molecular characterization,

Staphylococcus

aureus, Wounds

Article Info

Accepted:

26 December 2017

Available Online:

10 January 2018
In the present study, a total of 95 skin samples were collected from various districts of Rajasthan. Out of 95 skin samples, 67 samples were positive for dermatitis and 49 samples showed presence of different Gram's positive bacteria after growth on Mannitol salt agar medium. Out of 49 Gram's positive bacteria, only 30 (61.22 per cent) isolates could be confirmed as $S$. aureus through 23rRNA based ribotyping with an amplicon of $1250 \mathrm{bp}$.

\section{Introduction}

Staphylococcus aureus is gram positive, ubiquitous, pathogenic bacteria found mainly in nose and skin of animals. It is known to cause variety of suppurative infections and has always been a major cause of wounds and abscesses and mastitis in animals.

Over the past few decades the organism has come up as a leading cause of hospital and community acquired infection in human subjects causing endocarditis, deep-seated abscesses and bacteremia leading to toxic shock syndrome. The disease caused by $S$. aureus is not always fatal but an indirect great economical loss is incurred due to reduced working efficiency. The abscesses and wounds caused by $S$. aureus spread rapidly over the body surfaces and become very difficult to manage making animal useless for any economical purpose. The camel has a low susceptibility to diseases but skin involvements like contagious skin necrosis, dermatitis, wounds, abscesses or similar problems were commonly observed in camels 
(Rutter and Mack, 1963; Semushkin, 1968; Edlesten and Pegram, 1974; Domenech et al., 1977).

\section{Materials and Methods}

Bacteriological sampling, isolation and identification of Staphylococcus aureus

Bacteriological sampling in cases of superficial lesions

Top of pustule/papule or crust was lifted with a sterile 25 gauge needle. A swab was gently pressed on the exposed surface and allowed time for the contents to be absorbed. Then, swab was placed in sterilized nutrient broth medium, for further processing.

\section{Bacteriological sampling in cases of deep lesions}

The surface of the affected area was clipped and disinfected with 70 percent ethanol and allowed to dry. The area was then gently squeezed to express exudates and then sampled with swab.

Ajayi et al., (2013) reported that samples were inoculated on Mannitol Salt agar (MSA) and incubated at $37^{\circ} \mathrm{C}$ for $24 \mathrm{~h}$ and $48 \mathrm{~h}$. Colonies which appeared yellow on MSA were subjected for further tests. Examination indicated that the organism was Gram positive after the Grams staining technique and that they appeared in clusters and spherical (coccoid) in shape under the microscope.

\section{Genotypic confirmation of organisms by ribotyping}

The DNA was isolated as per the method described by Nachimuttu et al., (2001) with some modification. In brief, the overnight grown bacterial culture was pelleted, washed twice with five hundred $\mu$ LPBS and centrifuged 5000rpm for 5Min and resuspended in $1 \mathrm{ml}$ of Tris-EDTA (TE) solution. One hundred $\mu$ l of lysozyme solution (conc. $3 \mathrm{mg} / \mathrm{ml}$ ) was added and mixture was then incubated at $37^{\circ} \mathrm{C}$ in water bath for 15 min. One hundred $\mu \mathrm{l}$ of $10 \%$ SDS solution and $2 \mu \mathrm{l}$ of proteinase $\mathrm{K}(10 \mathrm{mg} / \mathrm{ml})$ solution was added, incubated at $60^{\circ} \mathrm{C}$ in water bath for $1 \mathrm{~h}$ with gentle mixing at $10 \mathrm{~min}$ intervals, then $0.75 \mathrm{ml}$ of DNA extraction buffer was added and further incubated for $30 \mathrm{~min}$ at $60^{\circ} \mathrm{C}$ in water bath. An amount of $0.5 \mathrm{ml}$ of penol: chloroform: isoamyl alcohol mixture $(25: 24: 1)$ was added to the DNA preparation and mixed gently for about 10-15 $\mathrm{min}$, mixture centrifuged at $15000 \mathrm{rpm}$ for $15 \mathrm{~min}$ at $20^{\circ} \mathrm{C}$ and upper aqueous phase containing DNA was transferred to another tube. To this mixture 0.5 $\mathrm{ml}$ of cold isopropanol was added and the tube was replaced on ice for $15 \mathrm{~min}$ and then centrifuged at $15000 \mathrm{rpm}$ for $10 \mathrm{~min}$ at $20^{\circ} \mathrm{C}$. The supernatant was discarded and the pellet was dissolved in $0.5 \mathrm{ml}$ of cold $70 \%$ ethanol and centrifuged at $10000 \mathrm{rpm}$ for $10 \mathrm{~min}$ at $20^{\circ} \mathrm{C}$. Supernatant was discarded and the tubes were inverted on a filter paper for $5 \mathrm{~min}$ and then left at room temperature for overnight to allow evaporation of alcohol. Next morning the pellet was redissolved in $50 \mu \mathrm{l}$ of $\mathrm{TE}$ buffer and left for $24 \mathrm{~h}$ for dissolution of the pellet.

The ribotyping based on $23 \mathrm{~S}$ rRNA gene was carried out as per the method described by Straub et al., (1999) using Primer-1 (5'ACGGAGTTACAAAGGACGAC-3') and Primer-2 (5'-AGCTCAGCCTTAACGAGT AC-3').

A total volume of $30 \mu \mathrm{l}$ reaction mixture for PCR was prepared by mixing $1.0 \mu$ primer- 1 $(10 \mathrm{pM} / \mu \mathrm{l}), 1.0 \mu \mathrm{l}$ primer-2 $(10 \mathrm{pM} / \mu \mathrm{l}), 1.0 \mu \mathrm{l}$ dNTP $(10 \mathrm{mM}), 5.0 \mu \mathrm{l} 10 \mathrm{x}$ Taq buffer A containing, 3.0 $\mu \mathrm{l} \mathrm{Mgcl}_{2}, 0.2 \mu \mathrm{lTaq}$ DNA polymerase $(5 \mathrm{U} / \mu \mathrm{l}), 11.3 \mu \mathrm{l}$ deionised water and $2.5 \mu \mathrm{l}$ DNA $(25 \mathrm{ng} / \mu \mathrm{l})$. 
Table.1 Site wise number of isolates used for 23SrRNA based ribotyping

\begin{tabular}{|c|c|c|c|}
\hline S. No. & Site & No. of sample & No. of isolates obtained (code numbers) \\
\hline $\mathbf{1 .}$ & Neck & 3 & $2(1,3)$ \\
\hline $\mathbf{2}$ & Chest pad & 4 & $3(7,15,24)$ \\
\hline $\mathbf{3}$ & Tail & 10 & $6(2,9,23,30,39,43)$ \\
\hline $\mathbf{4}$ & Abdomen & 3 & $1(35)$ \\
\hline 5. & Nostril & 4 & $2(27,41)$ \\
\hline 6. & Hump & 10 & $6(5,19,25,37,40,45)$ \\
\hline 7. & Fore Legs & 7 & $4(4,11,33,43)$ \\
\hline $\mathbf{8}$ & Hind Legs & 8 & $6(6,8,13,17,22,31)$ \\
\hline
\end{tabular}

Table.2 Isolates confined to be $S$. aureus based on 23SrRNA based ribotyping

\begin{tabular}{|c|c|c|c|c|} 
S. No & Gene type & Isolate numbers & $\begin{array}{c}\text { Total } \\
\text { isolates }\end{array}$ & $\begin{array}{c}\text { Amplicon } \\
\text { Size(bp) }\end{array}$ \\
\hline 1 & 23SrRNA & $\begin{array}{c}1,2,3,4,5,6,7,8,9,11,13,15,17, \\
19,22,23,24,25,27,30,31,33,35, \\
37,39,40,41,43,45,48\end{array}$ & 30 \\
\hline
\end{tabular}

Fig.1 Photograph showing yellow colonies of S. aureus in Mannitol Salt Agar

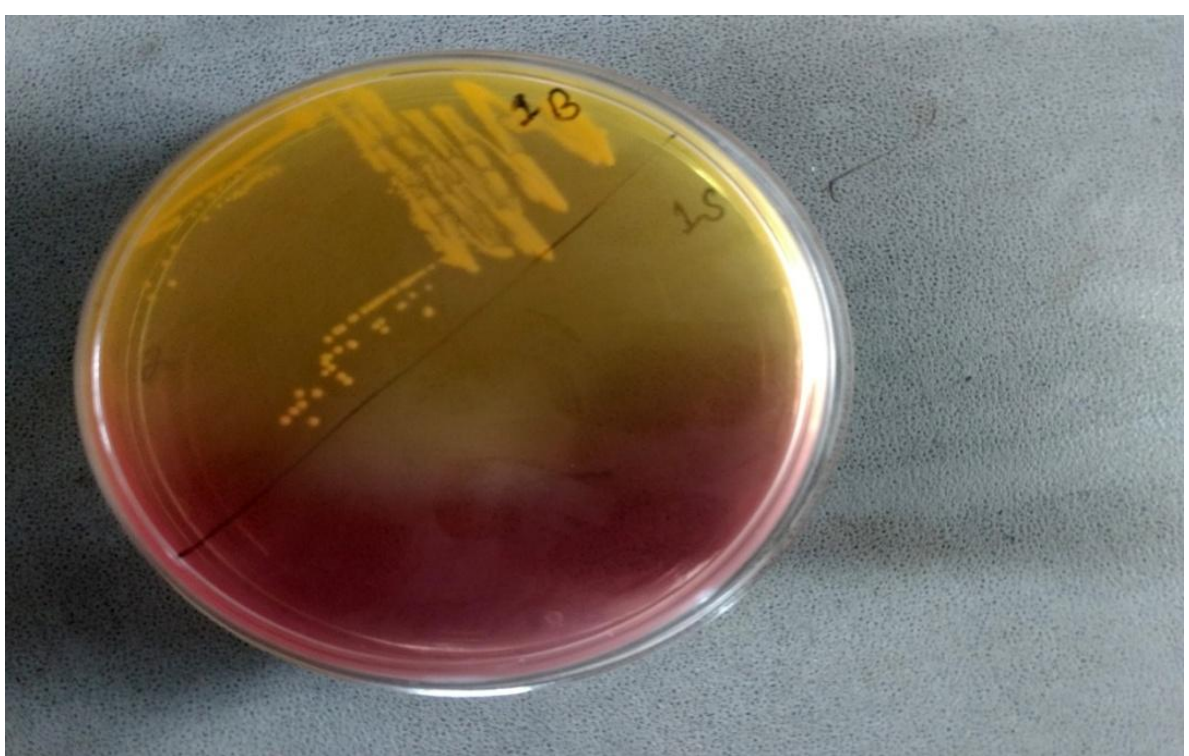


Fig.2 Photograph showing S. aureus grape cluster like morphology on Gram stain. 1000X

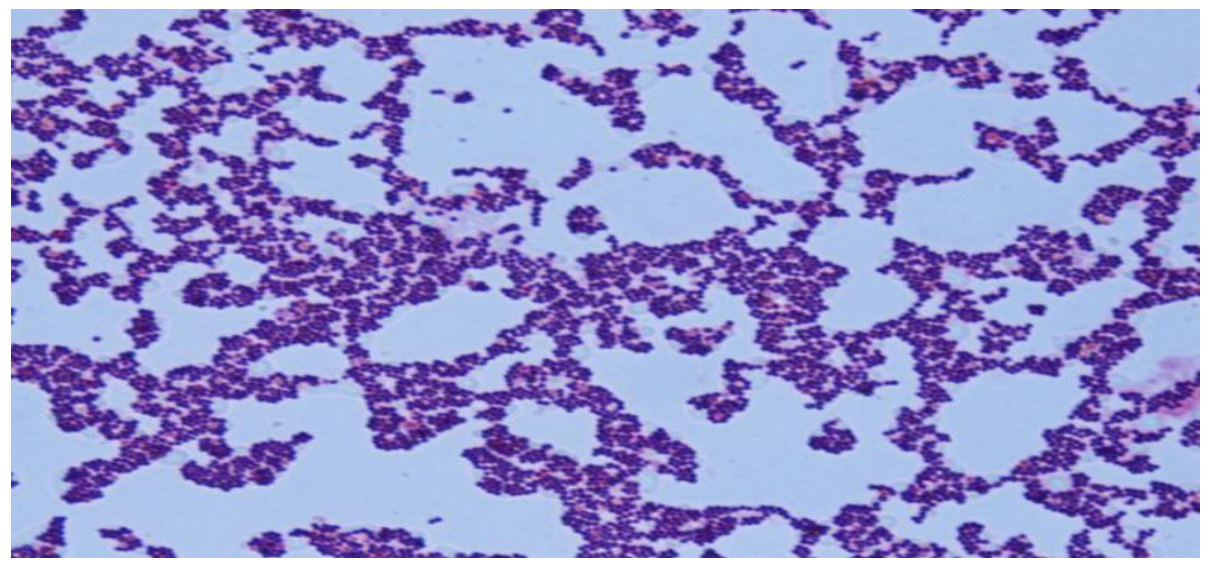

Fig.3 23SrRNA ribotypic of $S$. aureus obtained from camel skin lesions M-Molecular marker (250bp)

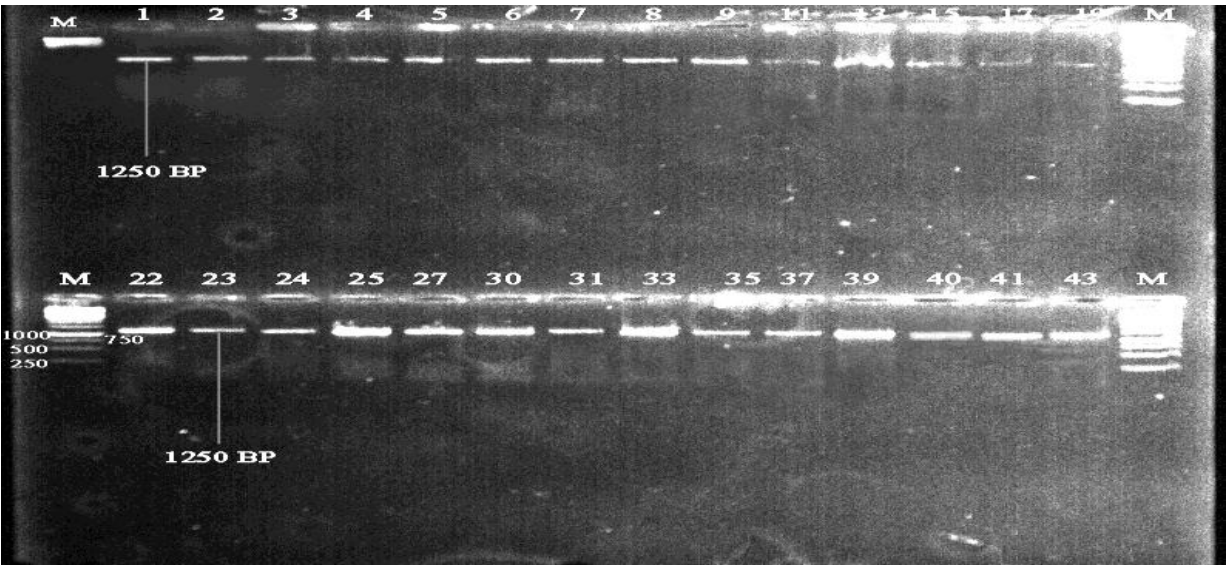

Fig.4 23SrRNA ribotypic of $S$. aureus obtained from camel skin lesions M-Molecular marker (250bp)

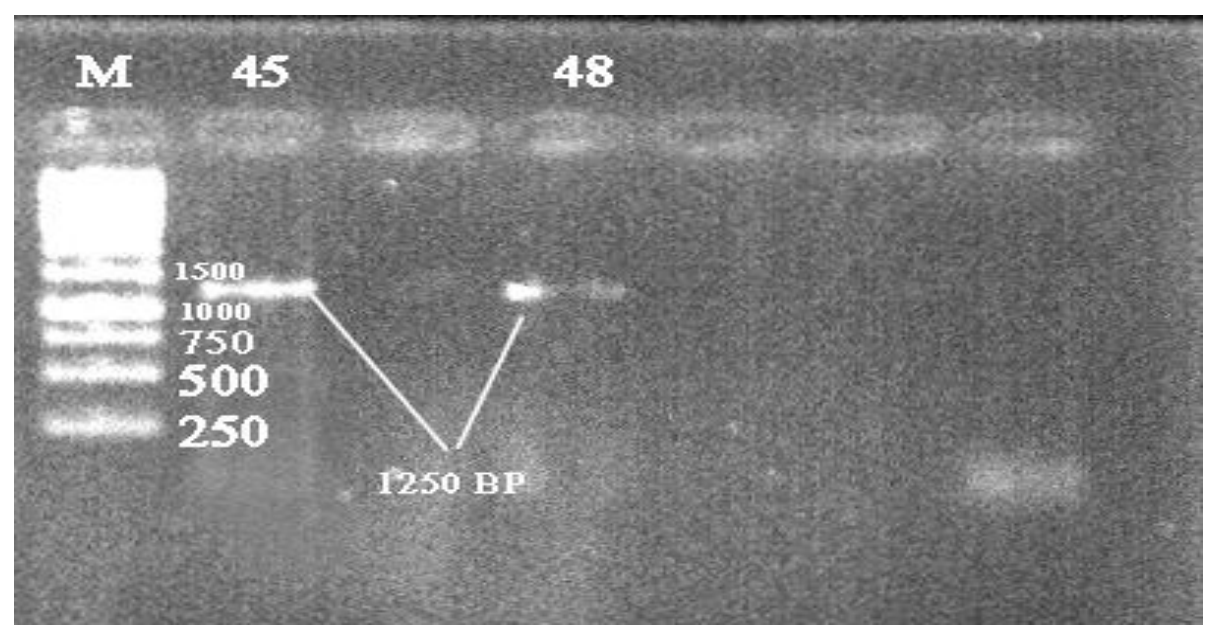


The denaturation, primer annealing and primer extension was carried out at $94^{\circ} \mathrm{C}, 55^{\circ} \mathrm{C}$ and at $72^{\circ} \mathrm{C}$, respectively, in each cycle and the time given for denaturation, primer annealing and primer extension for cycle $1 \mathrm{was} 300 \mathrm{sec}$, $30 \mathrm{sec}$ and $75 \mathrm{sec}$, respectively; for cycle 2-37 it was 40 sec, $60 \mathrm{sec}$ and $75 \mathrm{sec}$, respectively; and for cycle 38 it was $60 \mathrm{sec}, 60 \mathrm{sec}$ and $180 \mathrm{sec}$, respectively. The PCR products, after addition of $2 \mu \mathrm{l}$ of trekking dye were resolved in $1.0 \%$ agarose gels prepared in $1.0 \mathrm{x}$ TBE buffer containing $0.5 \mu \mathrm{g} / \mathrm{ml}$ of ethidium bromide and 250bp DNA ladder was used as molecular marker. The amplification products were electrophoresed for $1 \mathrm{~h} 30 \mathrm{~min}$ at $100 \mathrm{~V}$. The gel was then visualized under U.V. transilluminator

\section{Results and Discussion}

In the present investigation, out of 95 skin samples of camel, 49 samples showed presence of different Gram's positive bacteria after growth on Mannitol salt agar medium(Figs. 1 and 2). Out of 49 Gram's positive bacteria, only 30 isolates could be confirmed as $S$. aureus through 23rRNA based ribotyping with an amplicon of 1250 bp. (Table 1 and 2, Figs. 3 and 4).

In our study, the overall $S$. aureus prevalence was recorded as $61.22 \%$. Similar genotypic method of $S$. aureus identification have been used by Rathore and Kataria (2012), Ariyanti et al., (2011), Dhirenda (2016) for S. aureus isolates from elsewhere.

\section{References}

Ajayi, A. A., Aiyedun, B. T. and Olasehinde, G. L. 2013. The Effect of Hand Treatments on Staphylococcus aureus: A Normal Flora of the Human Palms. Adv. Biosci. Bioeng. 1(2): 44-53.

Ajayi, A. A., Aiyedun, B. T. and Olasehinde, G. L. 2013. The Effect of Hand Treatments on Staphylococcus aureus: A Normal Flora of the Human Palms. Adv. Biosci. Bioeng. 1(2): 44-53.

Dhirendra, M. 2016. Molecular typing of coa, spa, hla, cap (cap5 and cap8) genes polymorphism in staphylococcus aureus isolated from skin wounds of camel. M.V.Sc Thesis submitted to Rajasthan University of veterinary and Animal Science, Bikaner India.

Domenech, J., Gliidot, G. and Richard, D. 1977. Pyogenic diseases of dromedaries in Ethiopia. Rev. Elev. Med. et. Pays. Trop. 30(3): 251258.

Edelsten, R.M. and Pegram, R.G 1974. Contagious skin necrosis of Somali camels associated with staphylococcus. Trop. Anim. Hlth. Prod. 6: 255-256. (Cited from Vet. Bull. 45: Abst. 1547).

Nachimuttu, K., Ramadas, P., Thiagarajan, V., Dhinakar, Raj. G., and Kumanam, K. 2001. Laboratory manual on Polymerase chain reaction based methods for diagnosis. A workshop sponsored by NATP at Tamil Nadu Veterinary and Animal Science University from 21.02.2001 to 07.03.2001.5-13.

Rathore, P. and Kataria, A. K. 2012. Antimicrobial susceptibility profiling of Staphylococcus aureus of camel (Camelus dromedarius) skin origin. ABAH Bioflux. 4(2): 47-52.

Rutter, T.E.G. and Mack, R. 1963. Diseases of camels. Part I: Bacterial and Fungal Diseases. Vet. Bull. 33: 119-124.

Semushkin, N.R. 1968. Diagnosis of camel disease Sel'Khozgiz Moscow.

Straub, J.A., Hertel, C. and Hammes, W.P. 1999. A 23S rRNA target polymerase chain reaction based system for detection of Staphylococcus aureus in meat starter cultures and dairy products. Journal of Food Protection 62(10):1150-1156.

\section{How to cite this article:}

Chandra Pratap Singh, Manisha Mathur, Hemant Dadhich and Subha Ganguly. 2018. Molecular Characterization of Staphylococcus aureus of Camel (Camelus dromedarius) Skin Origin. Int.J.Curr.Microbiol.App.Sci. 7(01): 3486-3490. doi: https://doi.org/10.20546/ijcmas.2018.701.410 